gave an account of his use of multilayers for very varied purposes, such as the production of anti-reflexion, selective mirrors (for example, separating light and heat rays), polarization and monochromatic filters. P. Grassmann (Frankfurt) has constructed a small apparatus for liquefying air. $\mathrm{H}$. Vatter (Geislingen) described how to solder metal to ceramic so as to obtain high-vacuum containers for industrial use. F. Foerster (Eningen) dealt with a further development of the magnetic and eddy current methods for testing matter without damaging it.

A section on superconductivity was introduced by M. von Laue (Göttingen). He expounded a new theory which preserves all the good points of the former phenomenological theory, but avoids a difficulty which has arisen from the quantum theoretical (Heisenberg) assumption of a maximum density for the super current. The new theory achieves this improvement by replacing the relation between current density and super impulse, which was hitherto linear, by a more general relation.

$$
\text { it: }
$$

GABRIELE RABEL

\section{OIL-FIELDS OF NORTH-WEST} GERMANY

A STRUCTURA Amap of 20,000 square kilometres of north-yest Germany has been on view in the new building of the Department of Geology and Mineralogy at $8 x$ ford as part of the exhibition of oilfield devell pment held there to commemorate the opening of the building by the Vice-Chancellor on July 7. And the subsequent meeting of the Empire Mning and Metallurgical Congress. This map represents the greatest single contribution to tectonic geology to be published since the appearance of the tectonic map of the United States produced by the American Association of Petroleum Geologists under the guidance of the U.S. Geological Survey.

The map and explanatory handbook ${ }^{1}$ form part of the results of the team-work carried out under the leadership of Major A. E. Gunther (a graduate of the Oxford Geology School), who was in charge of the Government's oil-fields investigations in the British Zone of Germany in the two years after the end of the War. Accompanying this map there are in addition eight volumes of B.I.O.S. Reports (Nos. 1010-1017, British Oilfields Investigations ${ }^{2}$ ) covering every aspect of the development of the German crude oil industry from exploration to the technical and industrial structure of the industry.

As all who visited the exhibition at Oxford can testify, the map is a great achievement due to the co-operation of scientific and technical effort, which would not have been possible but for the close integration of academic and scientific with practical and industrial talent. It reflects the highest credit on the geologists of the German Geological Survey who have compiled the constituent sheets from a varied mass of data, and on their chief editor, Dr. Alfred Bentz; but above all on Major Gunther, who initiated the project and not only carried it through in most difficult circumstances but also so successfully overcame the political and other obstacles of the times that he receives in the introduction a high tribute from the German editor.

The exceptional scientific interest of the area was apparent to all in 1922 through the publication of Prof. H. Stille's pioneer "Ưbersichtskarte der Saxon- ischen Gebirgsbildung" on the scale of $1: 250,000$. At that time there were only four oil-fields in northwest Germany, two of which had been producing since the nineteenth century. The drive for German self-sufficiency in the 1930's led to great activity, which was, of course, intensified during the War. Between 1934 and 1945 the State covered the whole of north-west Germany with geophysical surveys and caused the drilling of some nine hundred subsidized exploration wells. In consequence, twenty-five new oil-fields were discovered and production was increased from 300,000 tons a year in 1933 to $1,000,000$ tons in 1940. This achievement is attributed largely to the institution in 1939 of a central authority to plan and carry through the work as a whole. The authority was at first the Reichstelle, which after 1941 became the present Reichsamt für Bodenforschung-the lineal descendant, but with greatly increased powers and scope, of the pre-war Preussische Geologische Landesanstalt, the scientific publications of which over many years earned it world-wide respect. After 1934 all crude oil was State property, and drilling was not only subsidized but also so directed as to ensure that the best technical methods were employed and that individual concessions were related to structures.

It is the scientific results of this great programme of exploration and exploitation that are gathered together and presented in co-ordinated form in the present map. For ten years the area was subjected to detailed and repeated geological and geophysical survey, by every available method, and to shallow and deep drilling. Some two hundred and fifty geological structures were revealed, of which about two hundred are salt domes. The map shows the oil structures at whatever depth they may lie, stripped of all obscuring strata, whether Quaternary, Tertiary or Cretaceous.

The work was initiated in August 1945 and completed a year later; but shortage of paper and diffi. culties of printing have caused delay. Some will see in it a value which transcends even its scientific achievement; for it is an inspiring example of international scientific and industrial collaboration which has overcome exceptional political and material obstacles to the attainment of a high scientific purpose.

W. J. ARKELL

${ }^{1}$ Erläuterungen zur Geotektonischen Karte von Nordwestdeutschland. 1: 100,000. Herausgegeben von A. Bentz. Pp. 235. (Celle: Reichsamt für Bodenforschung, 1949.)

Geotectonic Compilation Map of North-west Germany. Scale $1: 100,000$ in 26 sheets with volume of explanation. Pp. 235 Issued by Reichsamt für Bodenforschung, Celle. (Iondon

${ }^{2}$ Oil Fields Investigation, B.I.O.S. Final Reports, Item No. 30. Nos. 1010-1017 inclusive. (London: H.M. Stationery Office.)

\section{THE ELECTRICAL ENGINEER AND THE COMMUNITY}

$T$ HE presidential address of Prof. E. B. Moullin to the Inghytion of Electrical Engineers dealt in broad pripupla with the position of the professional electric 1 or ineer in the community, the nature of hif qual fication and the proper exercise of his function. In particular, the place of the Institution in relation to the profession was considered.

"Societies," said Prof. Moullin, "which are founded upon and which exact professional qualifications are a device for compromising rationally between unrestricted personal liberty and unrestricted compulsion, and thus are an important factor in 
maintaining a state of civilization. Viewed in this light they are seen to have a considerable degree of international status. Institutions of the same profession in different countries bear some resemblance to the local branches of a Universal Church, and the same is true of universities." There is, he suggested, a need for vigilance lest, in the modern State, the over-development of central administration should debase the true professional engineer into a mere specialist adviser to administrative boards.

Referring to the profession of electrical engineering, Prof. Moullin said : "A profession can be great without necessarily being learned. But we are essentially a learned profession, because the possibility of there being an electrical engineering profession depends, for its beginnings, on the highly intellectual and learned concepts of electricity. You cannot conceive of the Law as being anything but a learned profession because it depends, for its beginnings, on highly intellectual concepts. But there are other very great professions, possibly Medicine, where beginnings did not have to wait for the relevant purely intellectual concepts." The maintenance of standards of individual professional competence, he said, imposes upon the Institution an obligation to formulate a broad educational policy, although the Institution is not, in the conventional sense, an educational body. The essentially professional part of the electrical engineer's training is based on the industry, and "the distinction between those who have started at the university and those who have not done so" but have received their academic studies at a technical college, possibly on a part-time basis, "commonly becomes progressively more blurred as the years go on". The Council of the Institution does not favour a contemporary proposal to set up new technical colleges in which full-time undergraduate teaching in specialized branches of engineering would be carried on. "It is inevitable that engineers should be prominent in the affairs of man, in this era, and it is important to the welfare of contemporary civilization that those who are prominent should have had a broad education; this is obtainable in the university but is much less available in a monotechnic college. Recognizing the influence which engineers must have in the community, the Council are glad that a large number of those who enter our profession have been exposed to the good influences of a university during their student days." There is, in this connexion, a certain amount of misunderstanding in regard to the number of professional electrical engineers required by the industry of Great Britain. It is estimated that to meet the long-term demand an increase of only about ten per cent in the number of men qualifying annually is required. The present real shortage is in the number of trained technicians.

Prof. Moullin then referred to a recent decision of the Council of the Institution to foster and indeed to sponsor the setting up throughout Great Britain of a system of postgraduate courses of study in which leading exponents in the profession would make their specialized knowledge available to the general body of the engineering community. The physical framework of technical education in Britain is particularly favourable to this development, having, as we do, a large number of local educational centres in which such courses could be provided.

Prof. Moullin was somewhat sceptical as to the value of research training in the universities for young men who have just graduated, and he expressed a preference for the practice of bringing promising research men back into the university from industry at a later stage.

Examining in some detail the relation of the Institution to the profession, Prof. Moullin explained the practical significance of the charter and by-laws and discussed the constitution of the Council, the representation of the local centres and the constitution of the specialized Sections. "Because the Institution has existed for fewer years than our two great cousins, we are truthfully called the youngest of the three : but that statement can be misleading. It is only about 120 years since ideas and apparatus emerged to a point where Ohm's law could be recog nized, and only 108 years since $\mathrm{Ohm}$ was awarded the Copley Medal in commemoration of the discovery of his law, a discovery which brought technical application a whole range nearer. Without sensible error, we may call this the centenary of the birth of electrical engineering proper; and it is the 78th year of the Institution, which has therefore guided the development of the art for three-quarters of the time the art has existed."

J. G.

\section{THE JOHN INNES HORTICULTURAL INSTITUTION}

\section{ANNUAL REPORT}

$T$ HE annual repgrt of the John Innes Horticul. tural Institutor always succeeds in giving a large volum of results in relatively small space. That fo $1,94 \beta$ (from the Institution, Bayfordbury, Heftp. May 1949) is no exception. It will perhaps be nmenthered that the Institution recommended the raising of controlled hybrid raspberries, which would be free from vimus diseases which are not seedborne. D. Lewis and P. R. Day now review the results of five years of work on this question. They conclude that the hybrids are established more quickly than clonal stocks, yielding more in the first two years. Thereafter, virus infection takes place, when a virus-free clone of Norfolk Giant yields more than the hybrids. Seed of a new bush variety of tomato, named 'Puck', has been produced and released by M. B. Crane and A. G. Brown. It is early-maturing and heavy-cropping, but further breeding work is in progress. Genetic studies on pears have also been continued by M. B. Crane and D. Lewis ; the present report includes a brief analysis of the inheritance of fruit and vegetative characters.

The Genetics Department, under K. Mather, was concerned mainly with the organisation, properties and analysis of the polygenic systems which control quantitative or continuous variation. It now seems clear that there can exist within a single species genetic differences sufficient, when selected, to produce diversity as great as that between different species. Various systems of genetic isolation have been studied; in Petunia, for example, the too-unlike pollen is disfavoured as well as the too-like. In Antirrhinum, genetic isolation of some species depends on the pollen-style relation; but between $A$. majus and $A$. glutinosum it depends on insect behaviour, A. J. Bateman, studying the French bean, has also found somewhat comparable behaviour. This plant is normally inbred; but some varieties show a small percentage of out-crosses.

The director of the Institution, Dr. C. D. Darling. ton, reports work from the Cytology Department on differentiation in the pollen grain and the occurrence 